The mystery of Traditional Chinese Medicine has been attracting people for years. Acupuncture, ranked among the most common services of Complementary and Alternative Medicine, has recently gained a lot of interest in the scientific world. Contemporary researchers have been continuously trying to shed light on its possible mechanism of action in human organism. Numerous studies pertaining to acupuncture's application in cancer symptoms or treatment-related side effects management have already been published. Moreover, since the modern idea of acupuncture's immunomodulating effect seems to be promising, scientists have propounded a concept of its potential application as part of direct anti-tumor therapy. In our previous study we summarized possible use of acupuncture in management of cancer symptoms and treatment-related ailments, such as chemotherapy-induced nausea and vomiting, pain, xerostomia, vasomotor symptoms, neutropenia, fatigue, anxiety, insomnia, lymphoedema after mastectomy and peripheral neuropathy. This article reviews the studies concerning acupuncture as a possible tool in modern anticancer treatment.

Key words: acupuncture, anticancer treatment, cancer, complementary treatment, therapy.

Contemp Oncol (Pozn) 2016; 20 (6): 453-457 DOI: https://doi.org/10.5114/wo.2016.65604

\section{Acupuncture as anticancer treatment?}

\author{
Paulina Frączek, Aneta Kilian-Kita, Mirosława Püsküllüoglu, \\ Krzysztof Krzemieniecki
}

Department of Oncology Jagiellonian University, Krakow, Poland

\section{Introduction}

Complementary and alternative medicine (CAM) is defined by the National Center for Complementary and Alternative Medicine as a heterogeneous group comprised of a wide array of medical services that are not considered conventional medicine [1]. The use of CAM is widespread and increasing [2], hence the number of studies concerning its possible application in everyday clinical practice is also on the rise [3]. Acupuncture, subsumed under CAM, is one of the world's oldest medical procedures [4] and has gained a lot of interest and appreciation over the years [5]. The popularity of this method is continuously increasing [6]. It has been nearly two decades now since acupuncture was, for the first time, introduced in oncology as a possible tool in care of cancer patients [7]. A lot has been written about its possible application as supportive therapy in the oncology field and that issue was discussed in detail in the preview article published by our group [8]. Additionally, some publications suggest that acupuncture can possibly be part of a direct anti-tumor therapy, mainly due to its immunomodulating effect $[9,10]$. This review, as a continuation of the previously published study, is focused on the literature concerning acupuncture as antitumor therapy.

\section{Methods}

The material for the article was obtained from the literature search performed independently by two authors, in Medline/PubMed database (from 1990 to July 2014), the Cochrane Library (up to July 2014) and UpToDate. Following key words (in various combinations and forms) were used: 'acupuncture', 'CAM', 'immunomodulating effect', 'NK cell', 'activity', 'modulation', 'interferon gamma', 'complementary', 'anti-tumor', 'therapy' 'cancer', 'anticancer', 'treatment', 'oncology', 'application', 'electro-acupuncture', 'tumor volume', 'growth inhibition', 'immunotherapy', 'tumor response enhancement'. The foregoing phrases generated from several up to over 1100 results, depending on the source and specificity of searched issue (e.g. 'acupuncture' AND 'cancer' gives 501 results in Cochrane Library and 1153 in PubMed, whereas 'acupuncture' AND 'anticancer' generates 3 and 21 respectively). The 'RELATED CITATION' module in PubMed database was used in order to find additional articles. Only publications presenting acupuncture's direct or indirect anticancer effect were included. The results of studies based on animal model as well as human trials were analyzed. The ClinicalTrials.gov was searched to find information about currently ongoing clinical trials. Both full articles and abstracts were taken into consideration.

\section{Possible mechanisms of anticancer activity}

'The acupuncture immuno-enhancement hypothesis'

According to this theory, acupuncture enhances anticancer immunity of the human body by natural killer (NK) cells stimulation [11]. This hypothesis seems to be interesting since NK cells play a key role in regulating anticancer immune function and directly killing cancer cells [12]. NK cells use 
two mechanisms to kill cancer cells. The first one (secretory-cytotoxic mechanism) is mediated by the secreted cytolytic perforins and granzymes B (serine proteases), which damage deoxyribonucleic acid (DNA). The second one (non-secretory apoptotic mechanism) involves direct induction of apoptosis and is mediated by Tumor Necrosis Factor (TNF) family ligands located on NK cells membrane, e.g. Fas ligand (FasL). The second mechanism, which is more efficient and operative against all types of cancer cells, seems to be the major tool of NK cells activity [13-15]. Thanks to these efficient and highly selective killing strategies, NK cells are capable of detecting and eliminating newly formed and blood-borne cancer cells, and prevent the development of both primary tumors and their metastases [11].

The majority of the researches carried out so far on immunomodulatory effects of acupuncture have been focused on the stimulation of ST-36 acupoint, located on the pathway of the stomach meridian (Zusanli point, which is located $5 \mathrm{~cm}$ below the patella and $2 \mathrm{~cm}$ lateral of the anterior crest of the tibialis anterior muscle) [16]. Figure 1 presents hypothetic mechanism of acupuncture's effect on immune system.

Considering researchers' findings concerning the fact that acupuncture increases cytotoxic NK cells activity, it is intriguing to notice acupuncture' indirect effect on activity of antigen presenting cells (APC), especially on dendritic cells (DCs). These cells transform antigens from tumor dead cells and, presenting them to lymphocytes T, trigger initiation of the adaptive immune response[17]. DCs have also the ability to directly, selectively and effectively kill tumor cells through apoptosis by the engagement of ligands of TNF receptor family with the corresponding cancer cell receptors [18].

NK cells play an additional immunoregulatory function as they are capable of stimulating DCs, initiating their maturation in the bone marrow and significantly increasing their ability to produce pro-inflammatory cytokines and induce immune response mediated by $\mathrm{T} 1$ helper cells (Th1) and cytotoxic T lymphocytes (Tc) [19]. NK cells and DCs interactions are triggered by receptors and ligands of the TNF family receptors [20]. Increased NK cells efficacy in killing trans-

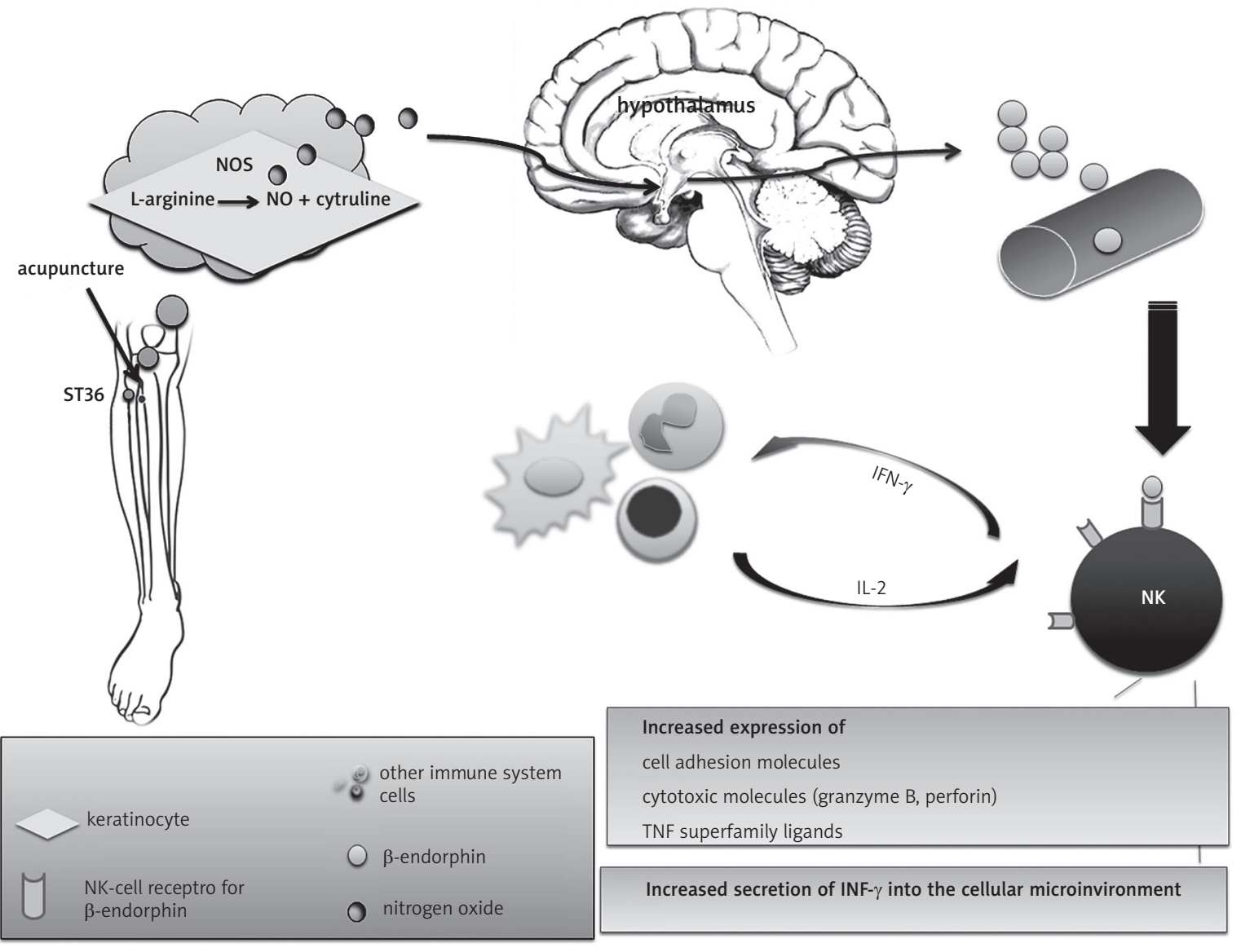

Puncture of ST-36 point induces NOS in the keratinocytes, which results in increased concentration of NO. NO transmits signal to the appropriate neural centers located in the brain, including the lateral hypothalamic field. This leads to the production of $\beta$-endorphin in this area that is followed by increased $\beta$-endorphin peripheral blood concentration. $\beta$-endorphins, binding to opioid NK-cell membrane receptors, activate NK cells and thus stimulate IFN- $\gamma$ production. IFN- $\gamma$ influences other immune system cells that produce IL-2, which is a strong NK cells stimulator.

NOS - nitric oxide synthase; NO - nitrogen oxide; NK - natural killer; IFN- $\gamma$ - interferon $\gamma$; IL-2 - interleukin 2

Fig. 1. Hypothetical model explaining how acupuncture stimulates the immune system (based on [11]) 
Table 1. Summary of possible immunomodulating effects of acupuncture

\begin{tabular}{|c|c|c|}
\hline $\begin{array}{l}\text { Possible immunomodulating } \\
\text { effects of acupuncture }\end{array}$ & Results & Ref. \\
\hline NK cell activation & $\begin{array}{l}\text { - direct antitumor activity through both secretory and non-secretory mechanism of } \\
\text { killing cancer cells } \\
\text { - induction of the secondary adaptive immune response by DCs and T lymphocytes }\end{array}$ & $\begin{array}{l}{[14,17,19,} \\
20]\end{array}$ \\
\hline SPI1 pathway activation & $\begin{array}{l}\text { - bone marrow stem cells stimulation } \\
\text { - proliferation and maturation of the immune system cells }\end{array}$ & [24] \\
\hline Increased IL-2 level & $\begin{array}{l}\text { - NK cells stimulation } \\
\text { - expression of } 1 \text { NKp44 receptor on NK-cell surface }\end{array}$ & {$[25,26]$} \\
\hline NO synthesis & $\begin{array}{l}\text { - NK cells activation } \\
\text { - induction of NK cells proliferation }\end{array}$ & [27] \\
\hline Increased endogenous B-endorphin & IFN- $\gamma$ synthesis & [28] \\
\hline Increased IFN- $\gamma$ level & $\begin{array}{l}\text { Mediates NK cell activity: } \\
\text { - increased expression of TNF superfamily ligands and NK cells receptors } \\
\text { - stimulate secretion of cytokines through other immune cells }\end{array}$ & {$[27,29,30]$} \\
\hline
\end{tabular}

${ }^{1}$ NKp44: NK-cell surface receptor, one of the major receptors responsible for triggering NK cell cytotoxic activity [26]

NK cell - natural killer cell; DC - dendritic cell; SPI1 - Spi-1 proto-oncogene; IL - interleukin; NO-nitrogen oxide; IFN- $\gamma$ - interferon $\gamma$; TNF-tumor necrosis factor

Table 2. Examples of studies concerning acupuncture's immunomodulating effects

\begin{tabular}{|c|c|c|}
\hline Study type & Results & Ref. \\
\hline Animal model & $\begin{array}{l}\text { Mice with transplanted mammary cancer } \\
\text { - significantly increased NK cell activity in acupunctured group in comparison to controls }(p<0.01) \\
\text { - higher degree of lymphocytic infiltration of tumor }(p<0.05)\end{array}$ & [9] \\
\hline Animal model & $\begin{array}{l}\text { - increased NK activity }(p<0.05) \text { and level of IFN- } \gamma(p<0.05) \text { in acupunctured group } \\
\text { - no significant difference in NK splenic population }\end{array}$ & {$[28]$} \\
\hline Animal model & $\begin{array}{l}\text { - significantly enhanced NK cell splenic cytotoxity }(p<0.001) \\
\text { - increased level of IFN- } \gamma \text { and IL-2 in comparison to non-acupunctured group }(p<0.01) \\
\text { - positive correlation between NK cells cytotoxity and the level of each cytokine was observed }(p<0.01)\end{array}$ & {$[29]$} \\
\hline Case series & $\begin{array}{l}60 \text { patients with metastatic colorectal cancer } \\
\text { - significantly increased level of NK cells in peripheral blood after acupuncture (patients with metastatic } \\
\text { colorectal cancer) }\end{array}$ & [10] \\
\hline Case series & $\begin{array}{l}17 \text { healthy volunteers } \\
\text { - increase in IFN- } \gamma \text { serum level and markers of peripheral NK cells activity: CD16+ }(p<0.05) \text { and CD } 56+\text { cells } \\
(p<0.01)\end{array}$ & {$[30]$} \\
\hline Lack of data & $\begin{array}{l}45 \text { patients with malignant tumors ( } 20 \text { controls) } \\
\text { - levels of IL-2 and NK cell activity significantly increased in study group }(p<0.01)\end{array}$ & [31] \\
\hline RCT (phase II) & $\begin{array}{l}51 \text { patients with malignant neoplasm, } 48 \text { healthy controls } \\
\text { - significant increase in the level of CDT3+, CDT4+, CDT8+ cells in acupunctured group }\end{array}$ & [32] \\
\hline Lack of data & $\begin{array}{l}40 \text { patients with malignant tumors ( } 20 \text { controls), acupunctured group exhibited: } \\
\text { - increased level of T lymphocyte subsets CD3+, CD4+, CD4+/CD } 8+(p<0.01) \\
\text { - increase in } \beta \text {-endorphin serum concentration }(p<0.01) \\
\text { - decreased level of solulable interleukin-2 receptor }(p<0.01)\end{array}$ & [33] \\
\hline
\end{tabular}

NK-natural killer; IFN- $\gamma$ - interferon $\gamma ;$ IL-2 - interleukin 2; RCT - randomized controlled trial; CD - cluster of differentiation

formed cells may additionally facilitate formation of antigen material derived from decomposing tumour cells, which, in turn, induces development of the secondary, adaptive immune response by DCs and T lymphocytes [11].

There is also suggestion that acupuncture works through the regulatory pathway of the Spi-1 proto-oncogene (SPI1). SPI1 encodes PU.1 transcription factor that masters the process of proliferation and maturation of the hematopoietic system cells [21]. To be more specific, it plays a special role in stem cells stimulation in the bone marrow and increases the number of mature NK cells [22]. In an experimental study carried out on animals, acupuncture has been found to induce an increase in the expression of c-Jun gene, which is a co-activator of PU.1 [11, 23] This finding suggests that acupuncture might work through the PU.1 pathway to regulate NK cells proliferation [23, 24].

Table 1 summarizes possible immunomodulating effects of acupuncture. Table 2 presents studies exemplifying acupuncture's role in stimulating the immune system.

\section{The acupuncture's anticancer effect}

In Table 3 research concerning acupuncture's possible direct antitumor activity was collected. Most of the 
Table 3. Studies concerning acupuncture as anticancer treatment.

\begin{tabular}{|c|c|c|}
\hline Study type & Results & Ref. \\
\hline Case series & $\begin{array}{l}\text { patients with superficial tumors underwent electroacupuncture: } \\
-123 \text { were CR } \\
\text { - } 129 \text { were PR } \\
\text { - } 36 \text { with their tumor shrinked by } 1 / 4 \\
\text { - } 32 \text { - no change in tumor size was observed } \\
\text { The ORR (CR + PR) was } 78.7 \%\end{array}$ & [34] \\
\hline Case series & $\begin{array}{l}106 \text { patients with liver cancer } \\
\text { - the ORR was the highest ( } 73.7 \%) \text { in the group where both electroacupuncture and liver artery intubation } \\
\text { chemotherapy were performed } \\
\text { - the other two groups of either electroacupuncture or liver artery intubation chemotherapy presented } \\
\text { with ORR of } 55.6 \% \text { and } 28.1 \% \text { respectively }\end{array}$ & {$[35]$} \\
\hline Case series & $\begin{array}{l}\text { Omura's ST36 point stimulation: } \\
\text { - decrease in cancer cell telomere, integrin } \alpha 5 \beta 1 \text { and oncogen C-fos Ab2 expression }\end{array}$ & {$[36]$} \\
\hline Case report & $\begin{array}{l}\text { 52-year-old woman with DCIS } \\
\text { - regression of DCIS after treatment with acupuncture }\end{array}$ & [37] \\
\hline Animal model & $\begin{array}{l}\text { Mice with transplanted mammary cancer } \\
\text { - acupunctured group exhibited less tumor volume }(p<0.01) \\
\text { - higher lymphocytic infiltration degree of tumor }(p<0.05)\end{array}$ & {$[9]$} \\
\hline Animal model & $\begin{array}{l}\text { Liver cancer, gastric cancer and hypodermic tumor rat models were obtained by implantation of replicated } \\
\text { Walker- } 256 \text { cell strain. } \\
\text { - the gross tumor volume in electroacupunctured group was significantly smaller than in control group } \\
(p<0.05)\end{array}$ & [38] \\
\hline Animal model & $\begin{array}{l}\text { Mice with implanted osteosarcoma - stimulation of ST36 acupoint: } \\
\text { - twice weekly beginning at postimplantation day 3: reduction in tumor growth, tumor lymphatics, } \\
\text { vasculature and innervation; marked reduction in pulmonary metastasis } \\
\text { - twice weekly starting at postimplantation day 7: significant increase in tumor growth }\end{array}$ & {$[39]$} \\
\hline Animal model & $\begin{array}{l}\text { Mice with inoculated Lewis lung carcinoma } \\
\text { - group of acupuncture combined with paclitaxel presented significantly lower tumor mass than in both } \\
\text { groups where either acupuncture or medication was applied }\end{array}$ & {$[40]$} \\
\hline $\begin{array}{l}\text { Systematic review } \\
\text { and meta-analysis }\end{array}$ & - enhancement of immediate tumor response & {$[41]$} \\
\hline
\end{tabular}

referred studies were conducted on animal models. The majority of the authors suggest that this method can effectively diminish tumor volume [9, 34, 37-39]. Also, some papers point to its potential application as additional therapy to the classic anticancer treatment $[35,40]$. One trial presents some of the molecular effects of acupoint stimulation, which were suggested to inhibit cancer cell activity [36]. It is essential to notice that results of one of the analyzed studies exhibited two opposite effects of acupoint stimulation, depending on the day of acupuncture initiation following transplantation of cancer cell into animal organism [39]. That, despite being the only report to be found to present tumor activity stimulation, can imply that the mechanism of acupuncture is still not being properly explicated, thus cannot be trusted enough to be introduced into clinical setting.

\section{Reliability of the studies}

The major problem of the research concerning antitumor activity is that it is scant. Although the results of the majority of presented studies are promising, some of them lack such elements as detailed methodology description, sufficient number of subjects, group characteristics or sta- tistical significance of results, which makes it difficult to assess and compare. Moreover, the alarming pro-cancer effect revealed in one of the referred studies indicates that due to the inconsiderable amount of data, further well-designed research is required.

\section{Summary}

Since recent studies have brought about a significant progress in immunotherapy of malignant tumours, the strategy of implementing acupuncture into clinical setting, based on its immunostimulating potential, seems promising [42]. However, as of today the potential combined use of this therapy with tumour immunotherapy in order to increase the efficacy of anticancer treatment can be seen only as an experimental approach. Both the quantity and the quality of data that is available for now require improvement and further scientific attempt in this field is needed.

The authors would like to thank Ms Joanna Gotab for editing the article.

The authors declare no conflict of interest. 


\section{References}

1. Engel LW, Straus SE. Development of therapeutics: opportunities within complementary and alternative medicine. Nat Rev Drug Dis cov 2002; 1: 229-37.

2. Kessler RC, Davis RB, Foster DF, et al. Long-term trends in the use of complementary and alternative medical therapies in the United States. Ann Intern Med 2001; 135: 262-8.

3. Edzart E. Complementary and alternative therapies for cancer. In: UpToDate, Hesketh PJ (Ed). UpToDate (Accessed on August 2014).

4. Andrew CA. Acupuncture. In: UpToDate, Mark DA (Ed). UpToDate (Accessed on August 2014).

5. Molassiotis A, Fernadez-Ortega P, Pud D et al. Use of complementary and alternative medicine in cancer patients: a European survey. Ann Oncol 2005; 16: 655-63.

6. Price S, Long AF, Godfrey M. What is traditional acupuncture - exploring goals and processes in the context of women with early breast cancer. BMC Complementary and Alternative Medicine 2014; 14: 201

7. NIH Consensus Conference. Acupuncture. Jama 1998; 280: 1518-24.

8. Kilian A, Püsküllüoğlu M, Konopka K, Krzemieniecki K. Acupuncture: could it become everyday practice in oncology? Contemporary Oncology; in press.

9. Liu LJ, Guo CJ, Jiao XM. Effect of acupuncture on immunologic function and histopathology of transplanted mammary cancer in mice. Zhongguo Zhong Xi Yi Jie He Za Zhi 1995; 15: 615-7. [Article in Chinese]

10. Zhao CL, Peng LJ, Zhang ZL et al..Effect of acupuncture on the activity of the peripheral blood T lymphocyte subsets and NK cells in patients with colorectal cancer liver metastasis. Zhongguo Zhen Jiu 2010; 30: 10-2. [Article in Chinese]

11. Johnston MF, Ortiz Sánchez E, Vujanovic NL, Li W. Acupuncture May Stimulate Anticancer Immunity via Activation of Natural Killer Cells. Evid Based Complement Alternat Med 2011; 2011: 481625.

12. Miller JS. The biology of natural killer cells in cancer, infection, and pregnancy. Exp Hematol 2001; 29: 1157-68.

13. Rousalova I, Krepela E. Granzyme B-induced apoptosis in cancer cells and its regulation (review). Int J Oncol 2010; 37: 1361-78.

14. Vujanovic NL, Nagashima S, Herberman RB, Whiteside TL Nonsecretory apoptotic killing by human NK cells. J Immunol 1996; 157: 1117-26.

15. Vujanovic NL. Role of TNF family ligands in antitumor activity of natu ral killer cells. Int Rev Immunol 2001; 20: 415-37.

16. Ma SX, Li XY, Sakurai T, Pandjaitan M. Evidence of enhanced non-en zymatic generation of nitric oxide on the skin surface of acupuncture points: An innovative approach in humans. Nitric Oxide 2007; 17: 60-8.

17. Lu G, Janjic BM, Janjic J, et al. Innate direct anticancer effector function of human immature dendritic cells. II. Role of TNF, lymphotoxin-alpha(1)beta(2), Fas ligand, and TNF-related apoptosis-inducing ligand. J Immunol 2002; 168: 1831-39.

18. Lakomy D, Janikashvili N, Fraszczak J, et al. Cytotoxic dendritic cells generated from cancer patients. J Immunol 2011; 187: 2775-82.

19. Kalinski P, Mailliard RB, Giermasz A, et al. Natural killer-dendritic cell cross-talk in cancer immunotherapy. Expert Opin Biol Ther 2005; 5: 1303-15.

20. Makarenkova V, Chakrabarti AK, Liberatore JA, et al. Dendritic cells and natural killer cells interact via multiple TNF family molecules. J Leukoc Biol 2005; 77: 408-13.

21. Scott EW, Simon MC, Anastasi J, Singh H. Requirement of transcription factor PU.1 in the development of multiple hematopoietic lineages. Science 1994; 265: 1573-7.

22. Di Santo JP. Natural killer cell developmental pathways: a question of balance. Annu Rev Immunol 2006; 24: 257-86.

23. Behre G, Coghlan MP, Hoang T, Carpenter CL, Davis RJ, Tenen DG. C-Jun is a JNK-independent coactivator of the PU.1 transcription factor. J Biol Chem 1999; 274: 4939-46.

24. Wang TT, Yuan WL, Ke O, et al. Effects of electro-acupuncture on the expression of c-jun and c-fos in spared dorsal root ganglion and as sociated spinal laminae following removal of adjacent dorsal root ganglia in cats. Neuroscience 2006; 140: 1169-76.

25. Wu B, Zhou RX, Zhou MS. Effect of acupuncture on interleukin-2 leve and NK cell immunoactivity of peripheral blood of malignant tumor patients. Zhongguo Zhong Xi Yi Jie He Za Zhi 1994; 14: 537-9. [Article in Chinese]
26. Vitale M, Bottino C, Sivori S, et al. NKp44, a novel triggering surface molecule specifically expressed by activated natural killer cells, is involved in non-major histocompatibility complex-restricted tumor cell lysis. J Exp Med 1998; 187: 2065-72.

27. Cifone MG, Ulisse S, Santoni A. Natural killer cells and nitric oxide. Int Immunopharmacol 2001; 1: 1513-24.

28. Yu Y, Kasahara T, Sato T, et al. Role of endogenous interferon gamma on the enhancement of splenic NK cell activity by electroacupuncture stimulation in mice. J Neuroimmunol 1998; 90: 176-86.

29. Yu Y, Kasahara T, Sato T, et al. Enhancement of splenic interferon-gamma, interleukin-2, and NK cytotoxicity by S36 acupoint acupuncture in F344 rats. Jpn J Physiol 1997; 47: 173-8.

30. Yamaguchi N, Takahashi T, Sakuma M, et al. Acupuncture regulates leukocyte subpopulations in human peripheral blood. Evid Based Complement Alternat Med 2007; 4: 447-53.

31. Wu B, Zhou RX, Zhou MS. Effect of acupuncture on interleukin-2 level and NK cell immunoactivity of peripheral blood of malignant tumor patients. Zhongguo Zhong Xi Yi Jie He Za Zhi 1994; 14 : 537-9. [Article in Chinese]

32. Yuan J, Zhou R. Effect of acupuncture on T-lymphocyte and its subsets from the peripheral blood of patients with malignant neoplasm. Zhen Ci Yan Jiu. 1993; 18: 174-7. [Article in Chinese]

33. Wu B, Zhou RX, Zhou MS. Effect of acupuncture on immunomodulation in patients with malignant tumors.Zhongguo Zhong Xi Yi Jie He Za Zhi. 1996; 16: 139-41. [Article in Chinese]

34. Xin YL, Liu DR, Meng X. Clinical observation on effect of electroacupuncture therapy in treating superficial tumor. Zhongguo Zhong Xi Yi Jie He Za Zhi. 2001; 21: 174-6. [Article in Chinese]

35. Xin Y, Liu D, Meng X. Clinical effectiveness of electroacupuncture therapy in combination with invasive therapy for massive liver cancer. Zhonghua Wai Ke Za Zhi 2001; 39: 756-8. [Article in Chinese]

36. Omura Y, Chen Y, Lu DP, Shimotsura Y, Ohki M, Duvvi H. Anatomical relationship between traditional acupuncture point ST 36 and Omura's ST 36 (True ST 36) with their therapeutic effects: 1) inhibition of cancer cell division by markedly lowering cancer cell telomere while increasing normal cell telomere, 2) improving circulatory disturbances, with reduction of abnormal increase in high triglyceride, L-homocystein, CRP, or cardiac troponin I \& T in blood by the stimulation of Omura's ST 36--Part 1. Acupunct Electrother Res 2007; 32: 31-70.

37. Dehen R. Regression of ductal carcinoma in situ after treatment with acupuncture. J Altern Complement Med 2013; 19: 911-5.

38. Lai M, Wang SM, Zhang WL, Wang Y, Huang SQ, Dong W, Li A. Effects of electroacupuncture on tumor growth and immune function in the Walker-256 model rat. Zhongguo Zhen Jiu 2008; 28: 607-9. [Article in Chinese]

39. Smeester BA, Al-Gizawiy M, O’Brien EE, Ericson ME, Triemstra JL, Beitz AJ. The effect of electroacupuncture on osteosarcoma tumor growth and metastasis: analysis of different treatment regimens. Evid Based Complement Alternat Med 2013; 2013: 387169.

40. Cheng ZD, Chen YG. Effect of acupuncture combined with intraperitoneal injection of paclitaxel on apoptosis in Lewis mice with lung carcinoma. Zhen Ci Yan Jiu 2007; 32: 153-7. [Article in Chinese]

41. Chen HY, Li SG, Cho WC, Zhang ZJ.The role of acupoint stimulation as an adjunct therapy for lung cancer: a systematic review and meta-analysis. BMC Complement Altern Med 2013; 13: 362.

42. McDermott DF. Immunotherapy of metastatic renal cell carcinoma. Cancer J 2009; 115: 2298-305

\section{Address for correspondence}

\section{Paulina Frączek}

Department of Clinical Oncology

University Hospital in Krakow

Śniadeckich 10

31-546 Krakow, Poland

e-mail: praczek@o2.p

Submitted: 9.12 .2014

Accepted: $\quad$ 15.10.2015 